\title{
Mudar de corpo em ode aos invisíveis
}

\author{
Cambiar de cuerpo en oda a los invisibles
}

Changing body in ode to the invisible ones

\author{
Ana Hupe'
}

Palavras chave:

Descolonização

Afrofuturismo

Imigração

Derivas urbanas

\section{Resumo:}

Este artigo entende a arte como processo de conscientização que se contrapõe à alienação imposta pelo sistema pós-industrial. As lacunas deixadas pela herança colonial são preenchidas com a força rítmica da caminhada e pelo encantamento com o afrofuturismo para desesteriotipar a África e Brasil como lugares do precário. Este texto sonha um mundo sem fronteiras, em que as sujeições identitárias escravizantes pulverizem no ar.

Descrições sobre a estada da autora na África do Sul, iluminadas por trabalhos de artistas como Sean O'Toole, Superflex, Sun Ra e OctaviaButler, fazem refletir sobre a importância de práticas de descolonização e de uma releitura dos fluxos migratórios. 


\section{Resumen:}

Este artículo entiende el arte como proceso de concientización que se oponea la alienación impuesta por el sistema posindustrial. Las lagunas dejadas por la herencia colonial son ocupadas con la fuerza rítmica de la caminada y por el encantamiento con el afro futurismo para desestereotipar África y Brasil como lugares de lo precario. Este texto sueña un mundo sin fronteras, en el cual las sujeciones identidarias esclavizantesse pulvericen en el aire.

Descripciones sobre la estada de la autora enSudáfrica, iluminadas por trabajos de artistas como Sean O'Toole, Superflex, Sun Ra y Octavia Butler, hacen reflexionar sobre la importancia de prácticas de descolonización y de una relectura de los flujos migratorios.

\section{Palabras clave:}

Descolonización

Afro futurismo

Inmigración

Derivas urbanas

\section{Keywords:}

Decolonization

\section{Afrofuturism}

Inmigration

Urban drifts

\section{Abstract:}

This article understands art as a process of awareness that opposes the alienation imposed by the post-industrial system. The gaps left by the colonial heritage are filled with the rhythmic strenght of the walk and the enchantment with Afrofuturism to de-stereotype Africa and Brazil as places of precariousness. This text dreams of a world without borders, in which the enslaved identitarian subjections pulverize in the air.

Descriptions of the author's stay in South Africa, illuminated by works by artists such as Sean O'Toole, Superflex, Sun Ra and Octavia Butler, reflect on the importance of decolonization practices and re-reading of migratory flows. 


\section{Mudar de corpo em ode aos invisíveis}
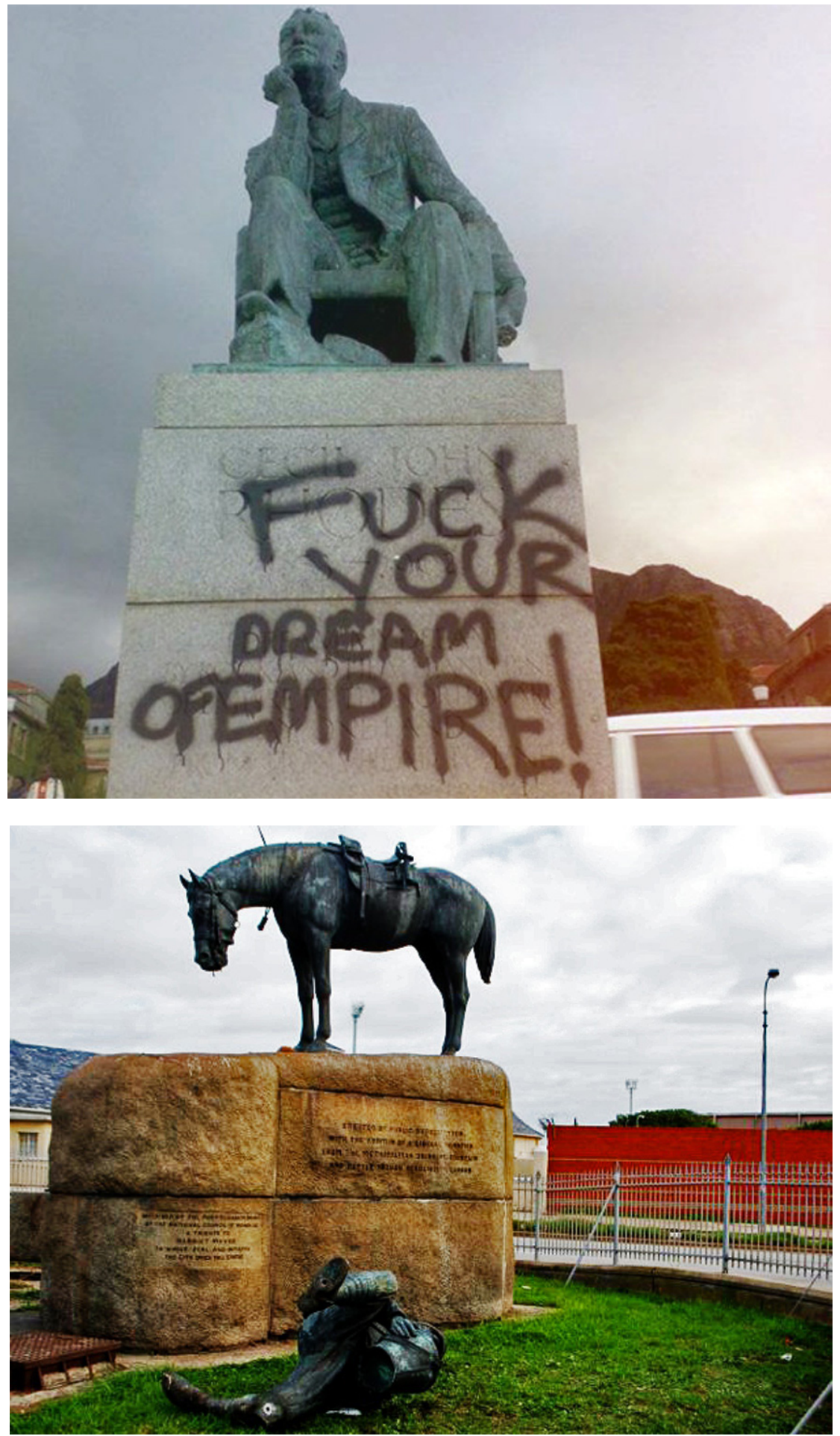

Imagens do movimento UCT Rhodes Must fall, organizado pelos estudantes da Universidade de Cape Town, (encontradas em: http://imagineathena.com/tag/rhodes-must-fall/ e em http://www.rnews.co.za/article/3535/statues-effed-part-5-security-around-his-torical-statues, acesso em setembro de 2016). O movimento atenta ao desequilíbrio de oportunidades entre negros e brancos nas universidades da África do Sul através dos símbolos coloniais presentes nos campi, como as estátuas e pinturas do acervo da UCT. 


\section{Afrofuturismo}

Entretanto, mais do que ênfase na angústia do espaço de descontinuidade, a batida é uma descarga de adrenalina alegre. O participante no ritual entra no portal do "trance" e encontra possibilidades de uma liberdade não ouvida no mundo da narrativa, o mundo da dominação hierárquica onde tempo e percepção são construções das classes e raças no poder. Para os descendentes de escravos, para quem

"trabalho" é ainda sublinhado pelas não-qualidades de um sistema baseado na branca dominação europeia e por rígidas classes hierárquicas, esse

"break" é um momento de liberação que está grávido de anseios históricos profundos e visões utópicas. (CHUDE-SOKEl, 2008, p.30)"

A batida da citação inicial é um espaço-tempo de elaboração, pausa para compor a revolução de uma utopia ainda refugiada, que no loop afrofuturístico ganha democracia. O loop, neste caso, refere-se à dinâmica da música eletrônica, despida de início, meio e fim, aonde entramos e saímos ao sabor do prazer, definindo o presente, o passado e o futuro, transformados em cometa. Numa fome de imaginar possibilidades para além do presente atual, de resistir à exploração linear da História, estruturada em modelos de hierarquias que guardam preconceitos, ficções de superioridade de uma cultura sobre a outra, volto minhas lentes ao afrofuturismo, termo que vem de artistas afrodescendentes da diáspora, nos EUA. Arquiteturas do afrofuturismo são o funk de George Clinton (das bandas Funkadelic e Parliament), o jazz do Sun Ra (Archestra) e o dub de Lee Scratch Perry (Black Ark), além das criações de DJs como Derrick May, de Detroit, que potencializaram as descobertas tecnológicas da Segunda Guerra Mundial, criando um loop a partir das batidas dos refrãos em sintetizadores, fervilhando as pistas com novos ritmos techno, harmonia do homem com a máquina.

Pelo estrangeirismo, a maior parte dos imigrantes são alijados da fala pública, como a maioria da população negra, e não participam do comum que constrói a política, não partilham do sensível, para lembrar Jacques Rancière ${ }^{\prime \prime \prime}$. (RANCIĖRE, 2004 , p. 22) Visto binóculos que me servem como veículo para alcançar a ficção científica inclusiva dos livros de Octavia Butler, de Samuel Delany e de Ishmael Reed e dos filmes do John Akomfrah.

A definição de afrofuturismo não cabe numa descrição enciclopédica, é como um artifício mágico para visibilizar os que estão à margem ou uma filosofia porosa e com identidade vaga; talvez uma filosofia de vida que mira o futuro da perspectiva de quem teve a voz suprimida por séculos a fio, como Anastácia, representante das escravas que eram castigadas por se recusarem a dormir com seus senhores. Foi forçada a usar um tapador na boca, a Máscara de Flandres, que permitia enxergar e respirar, mas não falar, como muitos escravos que trabalhavam nas plantações, obrigados a usar o tapador para não mascarem o caldo da cana, o café ou o cacau, castigo que também emudecia. O subterfúgio afrofuturístico elimina a máscara e usa, em seu lugar, a nave espacial como mídia para comportamentos subversivos, para desfazer a ligação inconsciente e imediata entre o negro e a escravidão. Pela dificuldade de expurgar resquícios de uma prática que orientou a economia mundial durante 354 anos, a invenção de estratégias fabulatórias aparece como maneira de contestar e sobrepor o arquivo colonial.

As ideias que apresento aqui vêm tanto do que vi e intuí nas ruas na África do Sul, onde passei dois meses e meio: 45 dias num programa de residência artística no Greatmore House Art Studios (Cidade do Cabo) e o resto do tempo, pela costa leste 
até Joanesburgo. Vêm também dos conceitos teóricos que me aproximaram pela primeira vez do afrofuturismo, quando fiz parte desta pesquisa em Berlim, na Universität der Künste. A triângulação Brasil - Alemanha - África do Sul foi fundamental para chegar a formulações expostas neste texto, permeadas de microhistórias pessoais, principalmente no tópico que descreve a experiência de campo na África do Sul, uma tentativa de restituir impressões a partir de vivências. Vivências diferem de experiência, porque são o vivido inseparável da construção de uma narrativa, um vivido preenchido por fragmentos de outras vivências de outras pessoas contadas a nós e renarradas.

Entendi na Alemanha a necessidade de me aproximar da África: o brasileiro está no meio do percurso, não é um nem outro, já dizia Silviano Santiago referindo-se ao mestiço, cuja principal característica é que a noção de unidade sofre reviravolta, é contaminada em favor de uma mistura sutil e complexa entre o elemento europeu e o elemento autóctone (SANTIAGO, 2000 , p.15). Faria bem ao purismo europeu misturar-se, prática brasileira desde 1500, quando os colonos portugueses utilizaram-se da assimilação para dominação, diferente do processo de colonização britânico, orientado pela segregação. A mestiçagem é rica e talvez tenha sido o fator que induziu a modernidade brasileira a acreditar no Brasil como o país do futuro, um bordão que nunca chegou à realidade do hemisfério Sul. Para desesteriotipar visões sobre a África e o Brasil, tomo a posição de trabalhar com a ferramenta afrofuturística, que dá ao continente africano, localizado no imaginário universal no lugar de passado, de mutilado, de miséria, um presente. $O$ recurso afrofuturístico facilita-me colocar no lugar do outro, operar invertendo papéis; é uma manobra que traz a possibilidade de quebrar a referência identitária que é escravizante, permite perceber a cultura africana, marcadamente negra, com emoções, tecnologia, política e, principalmente, enxerga os africa- nos antes do período das navegações europeias. Às vezes, esquecemos que houve um tempo anterior às colonizações, apesar dos primeiros indícios arqueológicos do homem terem sido encontrados na África: somos todos descendentes dos Khoi San da África do Sul (os nativos, conhecidos como bushmen). Os poucos homens da floresta que restaram, sobem até hoje à montanha, num ato de resistência ao modo de produção capitalista, colhem ervas e vendem nos Centros das cidades sul-africanas, como camelôs, vestindo tecidos de saco de batatas, mesmo no calor.

O termo afrofuturismo vem do livro de Mark Dery, Flame Wars, de 1993, embora em 1992, Mark Singer já escrevesse sobre ficção científica negra. Aqui é usado como uma tecnologia que serve ao discurso poético do colonizado - que quer nomear no lugar de ser nomeado, quer "direitos de significar". (BHABHA, 1998. p. 321) Apesar de experimentos afrofuturísticos terem aparecido com as histórias do escritor W.E.B. Dubois, há mais de um século, o movimento ganha força com a música, no período da luta contra a discriminação racial nos EUA, conhecido como Movimento dos Direitos Civis, entre 1954 e 1968. Socialista, marxista, mais reconhecido pela defesa do pan-africanismo ${ }^{\mathrm{IV}}$ e pela luta contra o preconceito racial e igualdade de gêneros, em 1930, Dubois escreve elogios sobre as relações entre negros e brancos no Brasil, depois de visitar o país. Interessada na suposta harmonia dessas relações, a Unesco, logo depois da Segunda Guerra Mundial, organiza uma expedição de pesquisadores ao Brasil para investigar o diálogo entre raças no país, mas a conclusão foi desanimadora: havia tanto racismo quanto nos EUA ou na Europa, embora manifesto de formas diversas ${ }^{\vee}$. (ANDREWS, 1997, p. 95-105).

No mundo afrofuturístico, das letras das músicas, mas também das invenções literárias e dos filmes, a captura do negro como escravo é reformulada como uma ab- 
dução alienígena, uma vez que ele foi retirado de sua terra natal, obrigado a esquecer sua própria língua e a se adaptar a um novo planeta, a colônia. Olhar os negros como alienígenas e imaginá-los em outros mundos é radical, porque os africanos tiveram sua imaginação sequestrada e formou-se uma narrativa dominante sobre o povo negro, que cria vidas limitadas. Juntar a África ao futuro é um passo para problematizar o legado de um inconsciente colonial, que ainda atravessa o Brasil, onde o gingado afrofuturístico encontra respingos, faíscas de um brasofuturismo que somando-se ao afro, transformam as ex-colônias em naves: é pelo ângulo de criar um mundo no espaço estreito da nossa herança africana que está a possibilidade de resistência, de rever a História.

Talvez pelo recente processo político de independência das metrópoles, que se deu no continente africano ao longo da segunda metade do século XX, o discurso descolonizador ainda é muito fresco na África, forte ao ponto de pensar que o Brasil esqueceu que foi colônia. Uma nova descolonização, em que corpos-monumentos-escritos-ritos contribuem para o não-esquecimento é o que cria o afrofuturismo, deixando-nos atentos às origens dos produtos, aos mecanismos de controle, à quantidade de açúcar que carrega uma latinha de Coca-Cola, distribuída de graça na favela em dia de domingo com show grátis na praça, para as crianças descalças fazerem fila e guardarem na memória a mercadoria daquele dia alegre.

As ideias afrofuturísticas foram primeiramente postas em prática pelos artistas, para depois tornarem-se filosofia fictícia pelo historicismo, conceito que ajuda na releitura da opressão história contra os negros e contribui para um reposicionamento de nós, humanos todos, como parte de um cosmos imenso, que não diferencia negro de branco, pobre de rico, as capacidades de mulheres e homens. Quebrando a divisão da sociedade em classes ou raças, o afrofuturismo, que repensa e reposiciona as estratégias dos co- lonizadores na África, aguça de forma imaginativa a análise dos privilégios de uns países em detrimento de outros e também a forma de operação colonial no Brasil, como nos constituímos no recalque da subjetividade, como diria a psicoterapeuta e crítica cultural Suely Rolnik, e reproduzimos as táticas dos colonizadores dentro do país, quando exploramos os nordestinos migrantes no Sudeste, por exemplo, enquanto a África do Sul, também parte dos BRICS (Brasil, Rússia, China, Índia e África do Sul), faz o mesmo com os trabalhadores imigrantes dos vizinhos Zimbabuê e Moçambique. No frescor do despertar, os "em desenvolvimento" poderiam experimentar um novo modelo para organizar as relações, ao invés de reproduzir as práticas coloniais. Ao inspirar formas fabulativas de agir, o afrofuturismo delineia ideais da África contemporânea para entendermos melhor como a potencialização do legado africano na literatura, arte e cultura brasileiras pode traduzir-se na formulação de um presente-futuro habitáveis com uma diversidade verdadeira. Rolnik percebe que somente agora, cinco séculos depois da invasão europeia, o Brasil consegue se livrar das imagens dos rituais antropofágicos que performatizam a tensão entre os povos que aqui viviam e os europeus que ocuparam suas terras, trazendo uma potência afirmativa para estas imagens, que modificam o modo como os efeitos do outro são vividos nos corpos. Estamos conseguindo reler Hans Staden, que descreve o Brasil como um país povoado por comedores de homens, selvagens, ferozes e nus. O livro foi um best-seller do século XVI na Europa, traduzido para 79 línguas, e narra a suposta verdade da relação dos indígenas com seu outro, quando de fato, é uma projeção da relação que os europeus estabelecem com seu outro. O recalque colonial vem do trauma e do massacre dos povos nativos e é um dispositivo eficaz de controle, que se mantém até hoje, apontando para saberes dos corpos a tal ponto humilhados que se inibem e interrompem. O afrofuturismo pode ser uma arma que ajuda a resgatar a confiança neste saber e fazer dele nossa bússola, para nos deslo- 
car da posição de humilhados e atualizar os elementos que para nós são inegociáveis, como era o ritual antropofágico para a cultura tupinambáv ${ }^{\mathrm{VI}}$, pode criar as condições para o retorno do corpo-que-sabe - livre das sequelas de seus traumas -, torna-se assim tarefa incontornável de resistência ao atual estado de coisas ${ }^{\mathrm{V}}$. Se mudarmos a relação com o outro, ativamos novos espaços de invenção nos nossos corpos, se olhamos para a cultura africana como lugar de potência, modificamos também a nós, habitados por ela.

As sociedades africanas, anteriormente ao período colonial, constituíram-se pela mobilidade e circulação, as migrações ocupando papel central nos mitos de origem africanos: não há um grupo étnico sequer que não tenha nunca se mudado. Os mais de onze idiomas oficiais num país com cerca de um quarto da população brasileira, como a África do Sulvilı, além das variadas moedas como o Rand, a Libra, o Yen ou o Dólar aceitas ao mesmo tempo no Zimbabuê, que já nem tem mais moeda oficial, são características que interessam cada vez mais a um mundo pós-internet, orientado pelo espírito do digital, que é flexível e instiga constantes inovações. A ideia de que a África é lugar de pobreza aonde se deve levar caridade é para turistas britânicos aposentados, o afrofuturismo elabora o continente como um laboratório de futuro, onde se pode colher. Com a chegada da eletricidade, que se estende à possibilidade de expansão dos canais de comunicação, o rural vem se urbanizando, convidando adeptos a um novo estilo de vida, assim como as cidades ganham suas hortas orgânicas comunitárias. No ar, um desejo à descentralização total, prometendo um tempo em que não haverá mais a separação entre rural e urbano. Enquanto o território europeu está todo ocupado, sem áreas livres para expansão, na África do Sul, ao contrário, viaja-se por quilômetros circundados por montanhas, por vezes com uma grade indicando propriedade privada, mas nenhuma construção.
No Brasil, também há muito espaço que pode ser ocupado com um novo sistema, mais comprometido com a liberdade, se anteciparmos a superação das fronteiras geopolíticas em função de um intenso tráfico virtual que obrigue a reformulação da ideia de Estado-Nação. Conseguiríamos, assim, uma transição a um mundo de livre circulação de forma organizada e pacífica. Uma mentalidade e identidade pan-africanas já são discutidas há tempos, contrariando as atuais construções de muros das nações do Hemisfério Norte. Em entrevista à Chronic, Mbembe comenta estatísticas de fluxos migratórios contrários aos que comumente aparecem nas manchetes de jornais, os de outros países em direção ao continente africano:

Falei a você sobre o um milhão de chineses. Em Angola ou Moçambique, nos últimos cinco anos, testemunhamos o retorno de 18.000 portugueses, muitos que deixaram o país durante a colonização, outros apenas chegando. Há pessoas chegando à África do Sul, marroquinos vindo do Norte e estabelecendo-se nas maiores cidades. (MBEMBE, 2015) ${ }^{1 \mathrm{X}}$

Mbembe vai concluir o pensamento aludindo ao Afropolitan Mindset, que seria uma evolução do pan-africanismo, algo que torna a África um ponto de encontro de diversos movimentos migratórios, uma mistura que aliada ao cosmos é capaz de iluminar a visão sobre a cultura brasileira, ativando saberes reprimidos dos nossos corpos e, por conseguinte, num plano maior, de elevar o lugar marginal ocupado por imigrantes no mundo, para que suas (nossas) falas reverberem.

\section{Práticas de descolonização: trabalho de campo na África do Sul}

Inspirada nos textos do escritor nigeriano Chinua Achebe, em Frantz Fanon e em poetas sul-africanos contemporâneos como Vonani Bila e Louis Chude-Sokei, 
que valorizam o microcosmo individual potente, trago relatos sobre o que observei na África do Sul. Somos catequizados desde a escola primária a nos afastar da escrita em primeira pessoa, na tentativa de alcançar um movimento que poderia ser "universal", termo ligado a valores e modos de vida europeus e norte-americanos. O ensaio Colonial Criticism (ACHEBE, 1978) constata que o grande elogio a um romance africano é quando a história pode se passar em qualquer lugar e pergunta se a mesma questão é posta em relação a um romance de John Updike ou de Philip Roth, se os críticos literários procuram localizar as histórias deles na África para testar se são universais, sugerindo uma extensão do horizonte universal que inclua o mundo todo. Voltar-se às vivências é uma forma de valorizar a presença física e a transmissão oral de conhecimento, que apesar de terem perdido espaço para o mundo digital, ainda são uma rica ferramenta de aprendizado.

Começo a caminhada deparando-me com a frase There are other worlds out here they never told you about, na sede da Chimurenga (luta pela liberdade, em shona), publicação e rádio PASS (Pan African Space Station) independentes da Cidade do Cabo, um centro vibrante de literatura, artes visuais e new music. Chimurenga fica no terceiro andar do Pan African Market, na Long Street, centro da cidade, onde quase não se veem brancos nas ruas, estão confinados nos carros, nas lojas, nos restaurantes ou nas casas com alarmes. Cheguei até lá obedecendo meus pés firmes a entrar em becos. Que importa a paisagem, a Glória, a baía, a linha do horizonte? - o que eu vejo é o beco. (BANDEIRA, 1936, 1978) Procuro o beco de Manuel Bandeira, porém num sentimento contrário à melancolia (Mal deux pais, mal do país) dele; sigo imbuída de uma euforia imensa. No beco, o já desaparecido esconde-se dos de pele clara, ensina que filho de negro com branco é light skinned e que alisar os cabelos é relax the hair, como se em estado natu- ral fossem tensos. A linha do horizonte do Centro de Joanesburgo também me convida a conhecer de perto seus prédios altos e luminosos que passariam a desavisados como uma paisagem de Xangai, mas que apresenta-se em ruínas, de perto. Os edifícios supostamente executivos são ocupados por uma população que inventa novos tipos de casa, dispõe varais coloridos e barracas de camelô na calçada em frente, ensinando que nem sempre as coisas são como se apresentam ao longe e que ficcionalizar não é somente drible simbólico, mas forma de sobrevivência. O historiador Michel de Certeau compara o ato de caminhar pela cidade - o contraste entre ver a cidade do alto de um prédio como um conjunto totalizante, onde o mapa urbano torna-se um gráfico que o olhar estratégico pode dominar a partir de uma base usada para gerir as relações com uma exterioridade de alvos ou ameaças (CERTEAU, 1994, p. 99); e a visão tática dos pedestres reapropriando-se dos espaços e dos detalhes do cotidiano, onde os corpos obedecem aos cheios e vazios de um 'texto' urbano que escrevem sem poder lê-lo.

Neste tempo, sou a única por dez quilômetros subindo a Market Street, uma das principais ruas do Centro, às duas da tarde e penso na separação por cor como a desculpa mais perversa para manutenção de privilégios, como mostra o conto do escritor suíço Friedrich Dürrenmatt, $A$ Epidemia Viral (1971), onde os brancos sul-africanos pegam um vírus e ficam negros, a começar pelo presidente, e passam a andar com uma placa no pescoço para diferenciá-los, identificando os negros-negros dos negros-brancos. Eram todos da mesma cor, mas importava a cor original, a camada subliminar que apontasse a linhagem. A Escrava Isaura, de Bernardo Guimarães, era notável pela exceção que representava na literatura: uma heroína supostamente negra. Entretanto, a personagem se afasta das características negras, como vemos na passagem: És formosa e tens uma cor linda, 
que ninguém dirá que gira em tuas veias uma só gota de sangue africano (GUIMARÃES, 1976, p. 29). Aliado ao aceleracionismo dos nossos tempos, o afrofuturismo pode ser usado a favor da digestão destes recalques históricos, cujo desaparecimento rápido poderia fundar corpos destemidos, que desafiem o Estado de segurança.

Não será com os mesmos corpos construídos por afetos que até agora sedimentaram nossa subserviência que seremos capazes de criar realidades políticas ainda impensadas. Mais do que novas ideias, neste momento histórico no qual a urgência de reconstrução da experiência política e a necessidade de enterrar formas que nos assombram com sua impotência infinita se fazem sentir de maneira gritante, precisamos de outro corpo. Para começar outro tempo político, será necessário inicialmente mudar de corpo. Pois nunca haverá nova política com os velhos sentimentos de sempre. (SAFATLE, 2016, p. 29)

Em corpos ainda traumatizados pelo extinto regime do apartheid, a língua das salas de aula e da comunicação entre brancos e negros, que desconheciam as fronteiras imperiais antes da colonização, é o inglês. Encontram-se placas de rua em três ou quatro idiomas diferentes, que respeitam a diversidade, mas o território comum é o inglês, língua com a qual nem todos se sentem confortáveis. A escritora Miss Milli $B$, de Joanesburgo, exemplifica a relação conflituosa até hoje dos negros sul-africanos com a língua inglesa $a^{x}$ : Esse homem negro sul-africano não tem nenhuma ambição em ser excelente no inglês." Ele achou interessante que eu o corrigisse numa língua que não é a dele, numa língua que não é minha. Ele disse que desejaria que eu tivesse feito a correção relativa à minha língua materna, o isiXhosa, que ele não fala. "Descolonizar é uma prática, sabe.", ele declarou. "Podemos nos comunicar na língua do opressor, mas eu não a respeito o suficiente para querer ser bom nela". Silenciei quando percebi que eu reencenava o que vi muitas vezes na infância e que ele externalizou. "Você me lembrou dos professores brancos que nos forçavam goela abaixo essa língua.", ele disse com um sorriso que desarmou minha posição defensiva de forma que essa troca desenvolveu como uma conversa entre professor e aluno. Não me senti pior do que me senti mal compreendida. Na minha cabeça, eu não era um dos julgadores anglofônicos negros porque "Sou consciente", estou "acordada", "entendo como o sistema opressor funciona."XI

Diferente do sistema segregacionista implementado na África do Sul, o ultracolonialismo português baseava-se na exploração bruta de matérias-primas e mão de obra e na ideologia de "Um Portugal", que favorecia o português como língua oficial única. Isso explica os candomblés, as macumbas, os espiritismos contemporâneos como resultado de embates e negociações entre elite e povo, brancos e negros, letrados e iletrados ao longo dos anos. Em Moçambique, o mesmo, brancos, mestiços e negros sentam juntos em mesa de bar, o que se observa com mais raridade nos países com histórico de colonização inglesa. Em comum entre os ainda em descolonização simbólica, os do "Sul Global", são cidades de nomes europeus ou apenas com o adjetivo "Nova" na frente, como New Barcelona ou Woodstock, em Cidade do Cabo. Penso no irônico nome da favela Nova Holanda, no Complexo da Maré, RJ, que remete imediatamente à característica da legalidade das drogas naquele país e naquela favela. A menos de vinte metros da movimentada Avenida Brasil, vendem pó em sacolas plásticas brancas ordinárias, de supermercado (a branca com um coração vermelho escrito "Zona Sul" denota o trânsito da cocaína pelas diferentes áreas da cidade), postas em cima das mesas de bar, como barraquinhas vendendo refrigerante no meio da rua, com crianças ainda uniformizadas da escola brincando correndo em volta. 
A estratégia de nomeação em homenagem é apropriada pelo Estado em Khayelitsha, maior "favela" (township, "navio da cidade", o que está de fora, ancorado no porto, à espera de autorização para pisar em terra) da África do Sul. O nome significa "novo lar" em isiXhosa, língua falada em Eastern Cape, estado sul-africano de onde muitos foram removidos e deslocados para começar aquela comunidade, em 1983. O Estado intitulou a nova área na língua dos vitimizados, Khayelitsha, o novo lar, que não tinha característica de casa alguma e hoje abriga 392 mil habitantes num mar de residências feitas com um material ondulante prensado (poliuretano?), arquiteturas de emergência, de resistência. As paredes ondulam, as portas, milhares de contêineres iguais à máquina do tempona Ceilândia de Branco Sai, Preto fica, filme de "ficção científica" de Adirley Queirós. Os tetos em ondas carregam pedras para não serem levados pelo vento, muito forte na região sul do continente africano, onde venta como em Jericoacoara, ponta nordeste brasileira, de frente para o mar aberto, cabelos embaraçados.
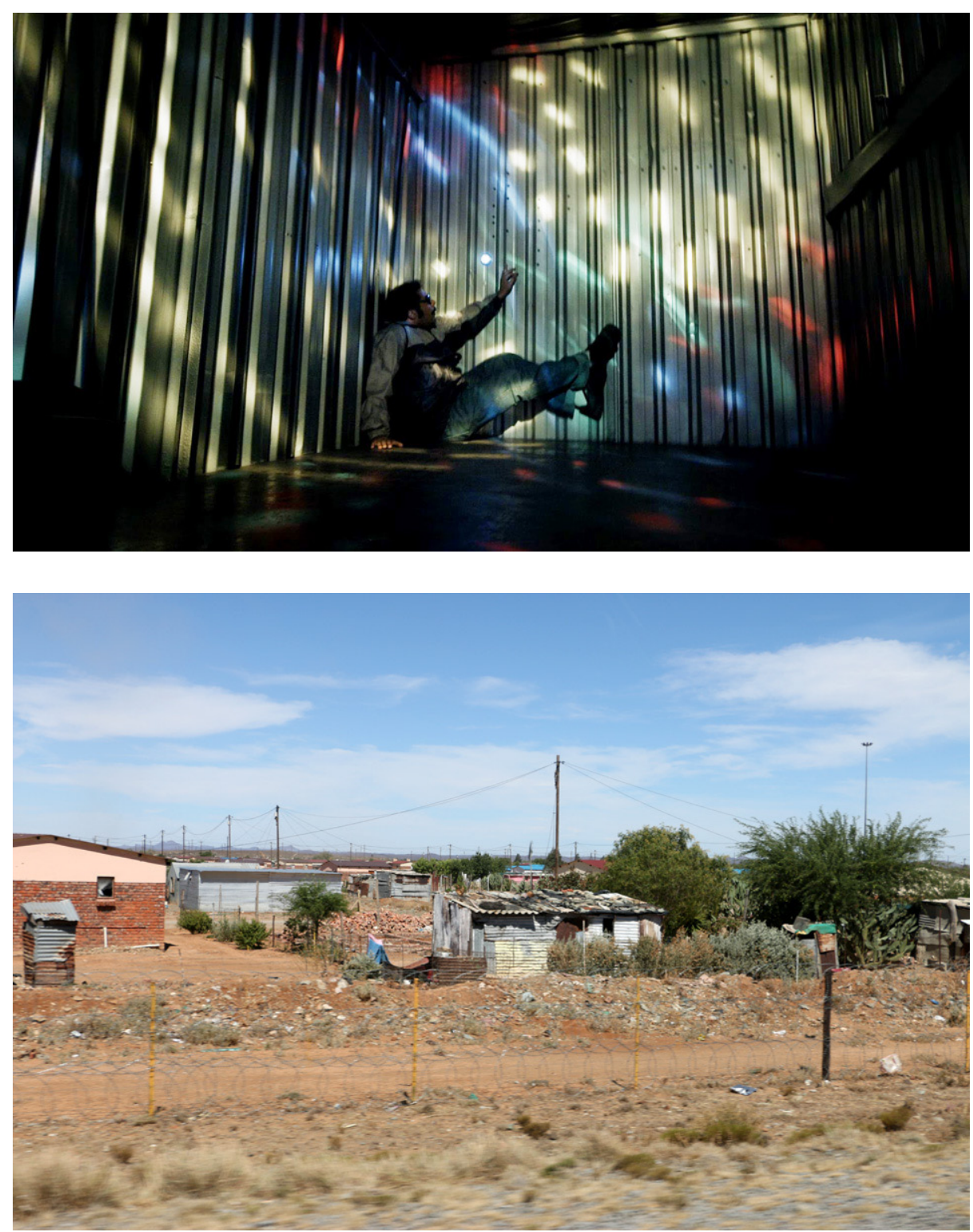

Contânier, máquina do tempo, em Branco Sai, Preto Fica, e container em favela na África do Sul. (Imagem encontrada em http:// www.papodecinema.com. br/artigos/confronto-branco-sai-preto-fica, setembro 2016 e fotografia pela autora). 

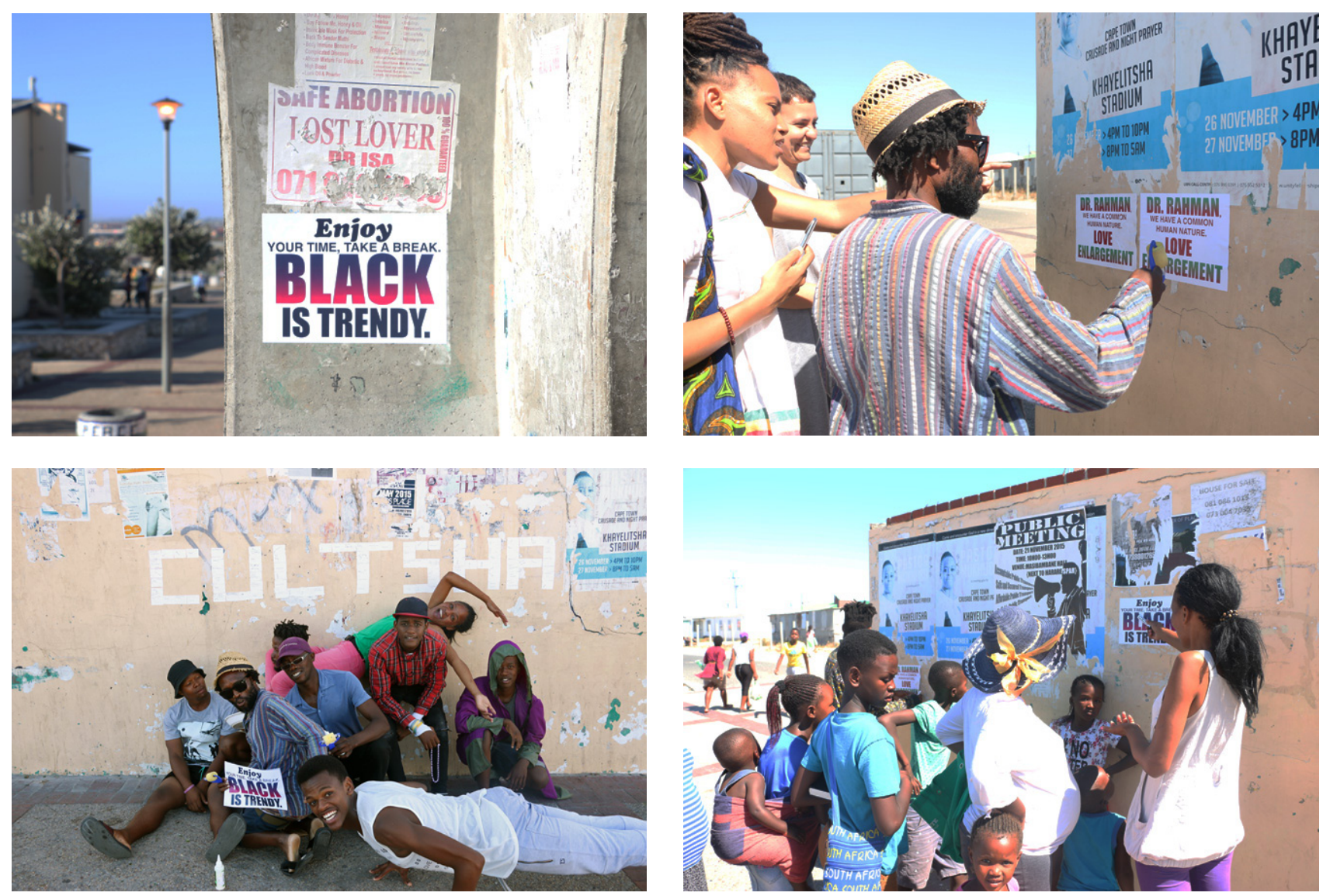

Imagens da oficina Literate Landscape, em Harare, Khayelitsha, África do Sul, 2016.

Realizada na The Harare Academy of Inspiration, com apoio das curadoras Brenda Skelenge e Valerie Geselev.

Numa jornada inclusiva àquela favela, conversei com os moradores-artistas, "poets of spoken words", muitos também rappers, cantores de hip hop. Organizei uma oficina no dia 02 de janeiro, descolonizando completamente o calendário escolar. Disse que seria sobre cartazes, porque estava bastante impressionada com as mensagens por toda cidade de "Safe abortion painless" ou "Penis Enlargement" ou "Lost lover, call Dr. Rahman" ou ainda pastores anunciando igrejas, inclusive a brasileira Universal do Reino de Deus, que tem uma sede enorme lá: "Jesus Christis the lord". Éramos um grupo de seis e propus que escolhêssemos uma palavra, cujas letras seriam construídas por post-its contendo mensagens nossas. Era preferível que a palavra tivesse seis letras, uma para cada um, embora a ideia da autoria coletiva apontasse para a mistura completa de bilhetes que compo- riam cada letra. Conversamos sobre black power, o orgulho negro e o dia a dia daqueles moradores, chegando a uma palavra: Cultcha. Em isiXhosa, a língua materna de todos ali, a pronúncia de Khayelitsha é Kalt'sha ou Kultsha, que quando escrita como se fala e com C, fica Cultcha, Khayelitsha misturada à cultura do muro.

Apropriar-se da estética comum às ruas para sobrepor conteúdos que valorizassem a população dali aos pôsteres locais era a nossa "missão afrofuturística". Assim, "Safe Abortion, Lost Lover" virou "Enjoy your time, take a break, Black is tren$d y$ " e ao Dr. Rahman, que trazia a pessoa amada e vendia produtos para aumentar o pênis, enviamos a seguinte mensagem: "Dr. Rahman, we have a common human nature, Love enlargement'. Por razões da história recente, uma das manifestações 
artísticas mais encontradas em ambientes populares é a poesia, que se tornou um produto do mercado pop africano global. Os slam poetry, rituais que se assemelham às disputas de MCs, têm influência hoje na periferia de São Paulo, por exemplox". $\mathrm{Na}$ África do Sul, na passagem dos anos 1990 para o ano 2000 , a poesia vai deixando um pouco de lado o tom político e ganha um individualismo, a influência do poeta norte-americano Saul Williams: palavras impregnadas do jogo do hip hop, num informalismo baseado menos na qualidade estética e mais na ressonância social como uma forma de contestar o escritor solitário e genial de romances, de valorizar o cara a cara, característica do hip hop. Em 2007, a poeta LeboMashile sai do palco para a tela da TV e inicia um programa de televisão que alcançou dois milhões de espectadores, transformando a poesia num sonho de carreira para muitos jovens.

Esta pequena cena de poetas e artistas de Khayelitsha exercita e ensina uma conduta descolonial que faz a máscara do neocolonialismo que assombrou a África e o Brasil do século XX, cair. Estabeleceram-se nesses países valores démodé, rejeitados pelas ex-metrópoles, centros de consumo que exportavam objetos fora de moda e também um discurso próximo ao do crítico de arte, porque apontava a uma economia deficitária. Cabe ao artista latino-americano dobrá-lo, enterrar o geneticismo e o discurso de fontes e influência para justificar um trabalho, atentar à deglutição dos artistas africanos, valorizando o apontamento das diferenças:

Olhar para o que não se olharia, escutar o que não se ouviria, atentar para o banal, o comum, o abaixo do comum. Negar a hierarquia inicial que vai do crucial ao anedótico, pois não existe o anedótico, e sim culturas dominantes que nos exilam de nós mesmos e dos outros, numa perda de sentido que, para nós, não é apenas sesta da consciência, mas um declínio da existência... (VIRILIO, 1988, 2015, p. 44).
No Observatory (bairro da Cidade do Cabo), a camiseta Africaisthe future desfila; o futuro é dispensar o carrinho e carregar criança nas costas como Canguru, encontrar nas estantes da livraria da esquina, uma seleção descolonizadora, onde ao lado do Chinua Achebe, do Ngebe, do Fanon, habitavam Philip Dick, William Gibson, prateleiras de ficção científica, gênero marginalizado dentro da literatura, chamado por Gibson de "Golden ghetto" (um gueto dourado é mídia perfeita para afrofuturar). A loja ficava ao lado do Straight no Chaser, casa de música experimental com as paredes cobertas por fotos dos músicos africanos negros exilados durante o Apartheid, cujo dono, Miles, um jornalista branco do Zimbabuê, sabia tudo de música e gesticulava numa performance que parecia coreografada, falando da força ancestral carregada na base da percussão - e apontava para o lugar do útero. Contou que o único ainda vivo da época da banda Blue Notes era o baterista Louis Moholo, que regressou há dez anos de Londres para África do Sul e dias depois, tocou na The Harare Academy of Inspiration, centro cultural na casa de Brenda Skelenge, em Khayelitsha, onde cheguei pela primeira vez pelas vias da música e imaginei o lendário do jazz, Moholo, no palco ao lado de Elza Soares, A Mulher do fim do mundo.

No Centro de Joanesburgo, o prédio Ponte City, cilíndrico de 173 metros de altura, o mais alto da África do Sul, foi construído em 1975 e logo invadido por gangsters e traficantes de drogas, como o edifício Rajah, da Praia de Botafogo, temido nos anos 1990 pela oficina de motos do $13^{\circ}$ andar ou pelos quartos usados como bordel. No alto do Ponte, havia um outdoor da Coca-cola que hoje é da Vodafone, luminoso e lembrando o Hotel Nacional, abandonado há mais de quinze anos, ao lado da Rocinha, sem que ninguém invadisse. A ficção científica brasileira clama por um realismo mais fantástico que construa um squatt à beira-mar. Curioso observar que o império do capital assemelha o estado do Ponte 
City e do antigo Rajah, agora chamado de Ed. Solymar. ambos foram comprados e reinaugurados após uma reforma estrutural. Não há o fora no capitalismo, ressoam Antonio Negri e Michael Hardt (2001), ideia que o afrofuturismo vai tentar desmentir, avisando que se não é possível um ocupa (ocupação de edificação abandonada) à beira-mar, que se inventem outras beiras atravessadas por outros mares.
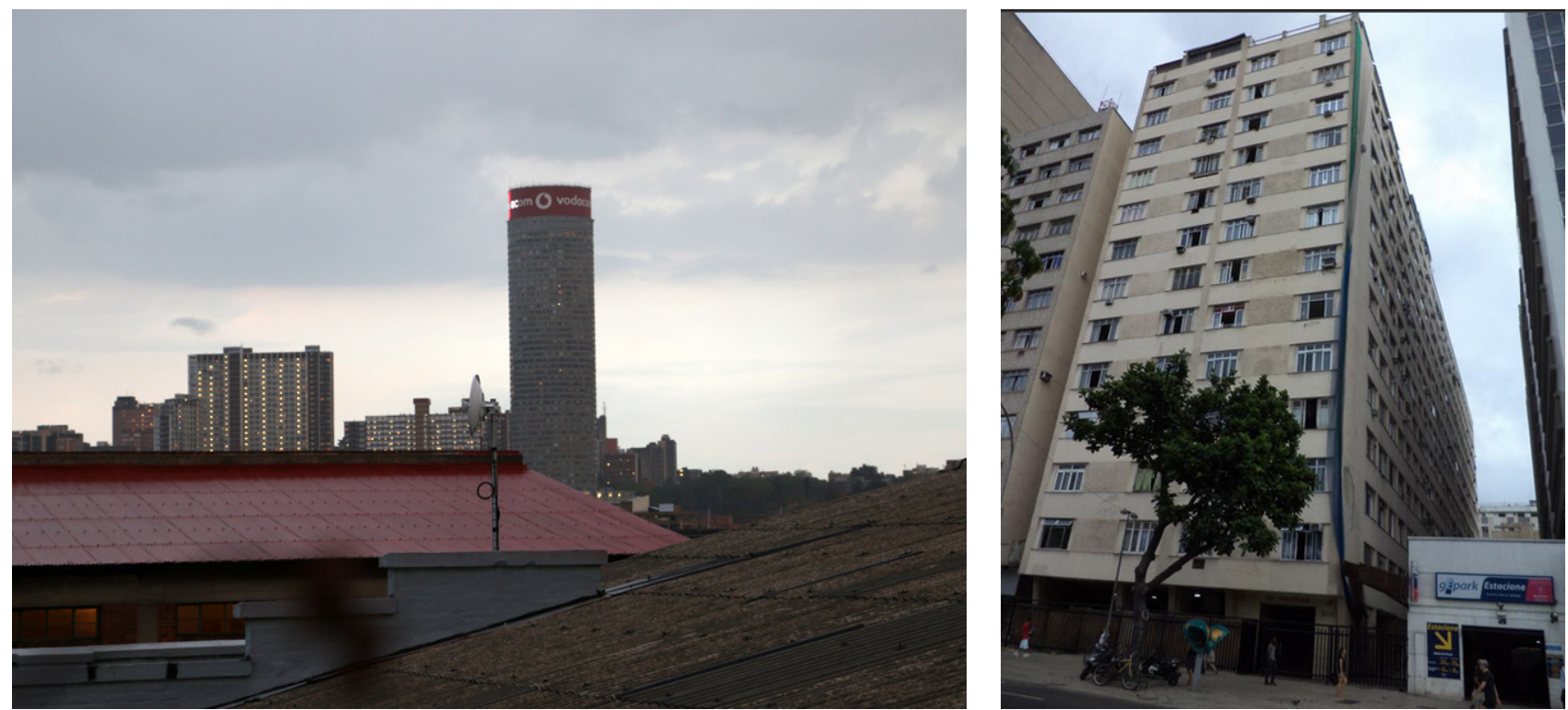

Ponte City, no Centro de Joanesburgo (imagem feita pela autora, 2016) e Ed. Solymar (antigo Rajah, na Praia de Botafogo, imagem encontrada em

http://wikimapia.org/27186345/pt/Edif\%C3\%ADcio-Solymar-Rajah\#/photo/5197268, acesso setembro 2016)

Logo depois de escrever sobre a precariedade tão óbvia quando pensamos África ou Brasil, tomo uma rasteira de Achille Mbembe, em On the post colony, onde ele critica a comum associação da África com o precário. A experiência humana africana só pode ser entendida através de uma interpretação negativa:

AÁfrica nunca é vista como possuidora de coisas e atributos propriamente parte da natureza humana. Ou, quando é, suas coisas e atributos são geralmente de menor valor, pouca importância, qualidade pobre. Em sua elementaridade e primitivismo, que fazem da África o mundo por excelência de tudo que é incompleto, mutilado, inacabado, sua história reduzida a uma série de revéses da natureza em seu quesito humanístico. (MBEMBE, 2001, p. 9) XIII $^{\text {II }}$
Jaílson de Souza e SilvaXIV, geógrafo fundador do Observatório de Favelas, na Maré (RJ), repete o mesmo discurso da zona sul em relação à favela. É pelo negativismo, do feio, do violento que este espaço de cidade é enxergado pelos moradores da elite, numa lógica que se repete. Na tentativa de dissociar esteriótipos, o afrofuturismo mostra a realidade digitalizante africana, com a torre wi-fi grátis no lugar de um orelhão em Braamfontein (bairro de Joanesburgo), com banquinhos em volta, onde muitos meninos brincam no celular depois da escola pelas ruas, por onde passam pessoas elegantes, saia justa até o joelho, salto-alto dourado, gravata colorida, celulares carregados por airtime, um pouco de tempo no ar e tranças nagôs feitas com Brazilian Hair. 


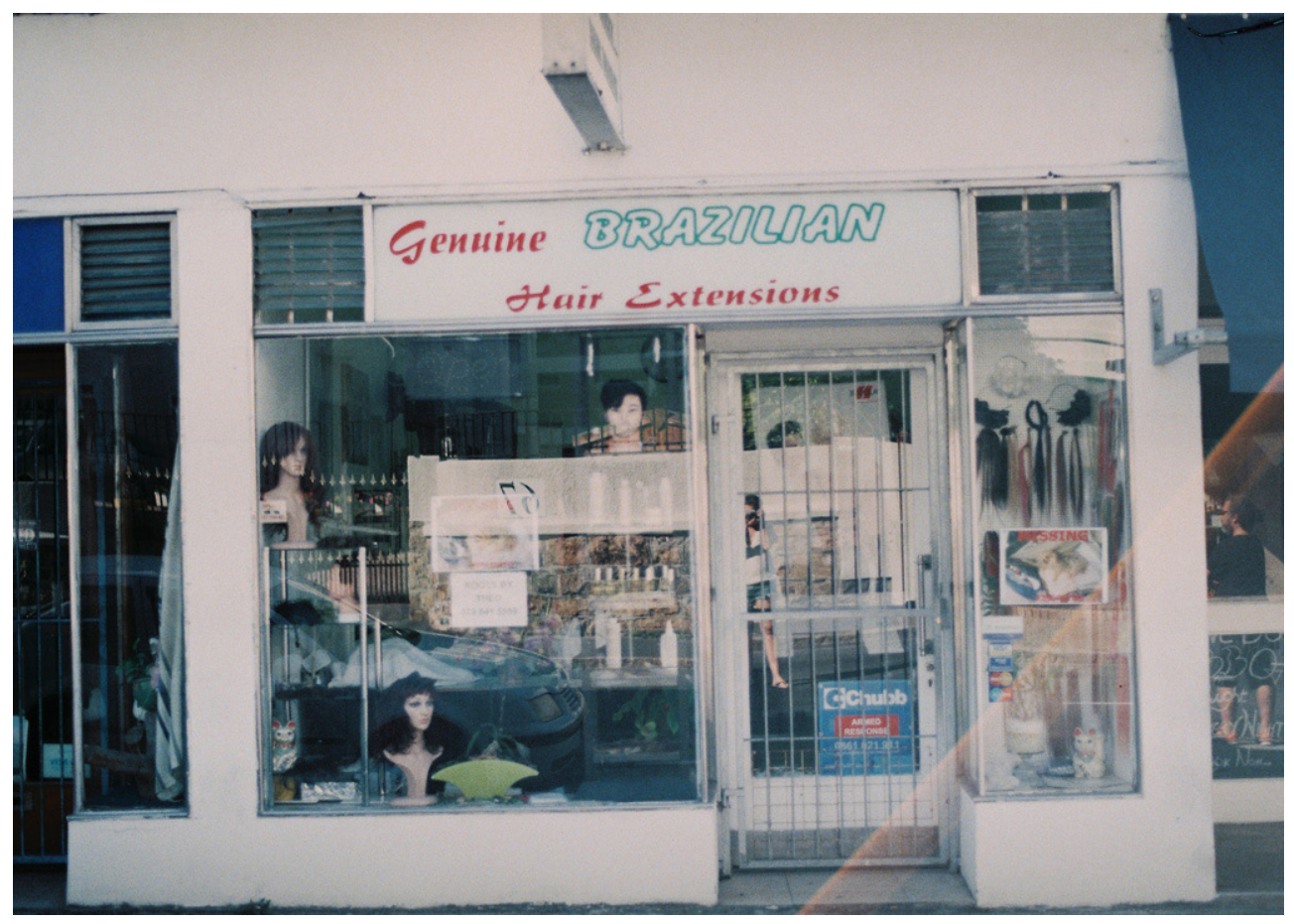

Fotografia feita pela autora na Cidade do Cabo, 2016.

Em inglês, tudo parece mais completo, para os em processo de descolonização, mesmo que chamem táxi ao que, na verdade, é uma van igual à "Central - Alvorada". De van ou a pé, é possível se libertar da retórica da economia de mercado, que pendura placas pela cidade apontando para o "Centro para resolução de conflitos", preocupada com a "transição total para a democracia" e com a engenharia social em geral, orientando-se pelo passado. A trilha escolhida para o passeio é a da África com potencial digitalizante que sempre teve, nos fones tocam Konono Nr.1, do Congo, TsheTsah Boys do Nozinja, com 200 milhões de visualizações no Youtube, um fenômeno na Nigéria, videoclipe e música criados por ex-técnico de computador de uma township, que aprendeu a usar os programas de mixagem de música e abalou a África inteira. Lembro do RD, também técnico de computador e produtor musical de funk da Maré (a rasteirinha coleciona milhares de likes no Youtube) e dos meninos do passinho.
À luz das palavras de Mbembe, a frase na saída do Museu do Apartheid, em Joanesburgo ressoa: "Liberdade, responsabilidade e democracia”. Infelizmente, ao lado da maioria negra, com seus cantos e danças pela igualdade, em 2016, ainda há uma minoria branca que carrega uma swástica escondida, como a que encontrei em Simon's Town, a uma hora de trem da Cidade do Cabo. Entre arquitetura inglesa predominante e pinguins africanos, resolvo espiar o que há por trás da placa "Toy's Museum" com a qual me deparo. Entrei direto, desatenta, até a primeira vitrine, onde estatelada, constatei uma passeata nazista de brinquedo, milhares de manifestantes com a swástica afrikaaner no braço (é uma adaptação da swástica do Hitler), uma alegria racista total para as crianças. Atônita, não ouvi os homens do balcão de entrada alertando para a necessidade do pagamento de um ticket para o museu. Não consegui reagir no reflexo, depois enumerei mil possibilidades do que poderia ter dito. Saiu apenas "- Coisas estranhas os senhores têm aqui", ao que responderam, "- Tem gente que gosta”. Logo à frente avisto uma 
placa de uma empresa de construção civil com a logomarca parecendo uma swástica adaptada. Na Alemanha, é inconcebível uma swástica circular sem explicações, mesmo de maneira subliminar, e por estar acostumada com a violência deste símbolo, saí impactada pela mensagem travestida de brincadeira, de dentro daquele museu privado. CompartiIho da revolta que o povo negro sul-africano dissipa, dissimula, em nome da democracia, querendo crer na igualdade. A Organização das Nações Unidas chegou a proibir a venda de produtos derivados do petróleo vindos da África do Sul até que a pressão internacional ficasse insustentável e obrigasse os brancos a abrirem a mesa de negociações para acabar com o Apartheid. Sinto glória no ar, o mundo inteiro em crise e na África do Sul, a crise é a prosperidade, é o caminhar de dreads orgulhosos, coloridos, é um salão de tratamento de cabelos lotado em cada es- quina, é elegância sem marca, sem etiqueta. Em um vídeo documental a que assisti no Museu do Apartheid, Winnie Mandela se levanta e incendeia: "- Não temos armas, mas temos petróleo e caixas de fósforos". Fizeram uso destes fósforos os estudantes que, em 16 de fevereiro de 2016, como parte dos protestos \#feesmustfall e \#rhodesmustfall, contra o privilégio de brancos nas acomodações estudantis no campus da Universidade da Cidade do Cabo (UCT) e a privatização do ensino público no país; queimaram pinturas coloniais que eram parte da coleção da Universidade de Cape Town, numa fogueira em frente à UCT. Rhodes must fallé um movimento que começou em março de 2015, quando estudantes e equipe da UCT se organizaram para clamar pela remoção da estátua de Cecil Rhodes do campus, para, simbolicamente, apontar à queda inevitável da supremacia branca e do racismo ali.
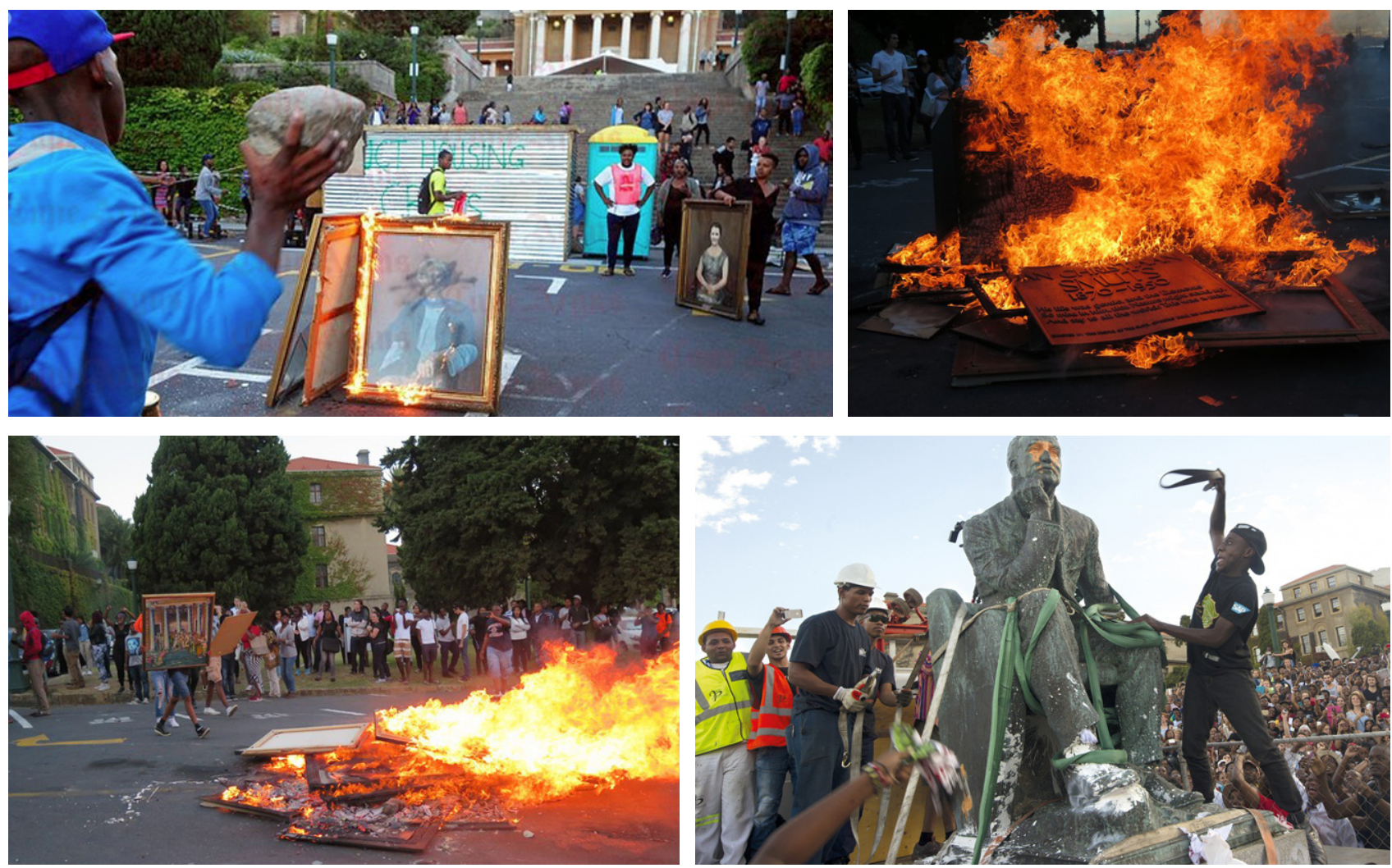

Imagens de 16 de fevereiro de 2016, no campus da UCT.

(encontradas em http://www.groundup.org.za/article/rhodes-must-fall-protesters-destroy-uct-artworks/ e http://www.newstatesman.com/politics/uk/2016/02/rhodes-must-fall-any-debate-money-talks, acesso em setembro de 2016.) 
Houve poucos, porém alguns brancos, indianos e mestiços que se envolveram na luta anti-apartheid, como Ruth Slovo e Dr. Neil Agget, torturado até a morte, na prisão de Robben Island. Ainda assim, sentir-me adrenalada de medo andando pelas ruas é como vestir a pele de uma segunda categoria. Joanesburgo é uma Black city que tenta me enjaular o tempo todo, mas a contragosto das recomendações, atravessei a ponte Nelson Mandela. Braamfontein é "seguro", cheio de lojinhas design, cafés com capuccino, galerias de arte exibindo fotos PB dos cabelos afrodreads. Do outro lado, espetinhos de carne, biltongs, tecidos coloridos, costureiras e costureiros pelo meio da rua, milho no grill, Náiques fake (muitos), "eternal happiness, call now!!!", um frio na barriga ao atravessar embaixo do viaduto ao lado de dois moleques carregando um pedaço de pau. Descobri um coletivo de Soweto, comunidade onde Nelson Mandela morava, em Joanesburgo, chamado Smartees, formado por jovens estilistas que criam uma moda baseada em roupas de grifes italianas falsificadas (made in China). A glamourização do falso, a ironia da cópia, é um caminho para denominarmos e depois, salvarmos o mundo simbólico do Sul.

\section{Só a ficção salva}

Quando toda a realidade parece tender a um fim, o ensaio The Truth of Fiction (ACHEBE, 1978), aponta para a força da ficção e o papel da arte em persuadir a imaginação e distribuir valores culturais que desmantelem autoritarismos, como Guernica, de Picasso, que foi um esforço em criar uma nova ordem de realidade, uma faceta existencial contraposta ao fascismo. $\mathrm{O}$ artista inventa para sair dos problemas (não fugir, mas encontrar soluções), como as crianças que inventam papéis para si, fingem que são pai e mãe ou professor e aluno. Falta ao Centro o poder da imaginação, a capacidade de recriar a si mesmo através dos olhos dos outros, de se colocar no lugar do outro e a literatura e a arte são vias para a identificação.
Uma pessoa insensível ao sofrimento dos demais na sociedade não exercita a imaginação, da qual, muitas vezes, o privilégio é um adversário, criando uma grossa camada sobre a sensibilidade, que a distancia do mundo. O artista não possui classe social; almoça com o presidente e janta com o morador de rua; atravessa a divisão de classes exercitando a imaginação a partir da identificação, a conexão humana no seu lugar mais íntimo. Na medida em que exercita uma reinvenção da memória coletiva para lançar projeções, o afrofuturismo quando aplicado à realidade brasileira, é capaz de reformular a função do pobre, do periférico e desamarra a narrativa social encontrada nos jornais, lança a possibilidade de ficção ao narrador periférico, que deixa de lado o lugar de sofrimento ou crime, onde a sociedade o coloca e onde ele mesmo se vê, para deixar fruir o pensamento.

O já citado filme brasileiro Branco Sai, Preto Fica, de Adirley Queirós, criado na Ceilândia, periferia de Brasília, termina com a frase "a nossa memória, fabulamos nós mesmos", numa vontade de mostrar que a memória tradicional é reacionária, embala o passado numa cápsula como se tivesse sido um tempo bom, embora tenha sido horrível. O filme trata da amputação dos corpos periféricos pelo poder, espelha a realidade da UPP proibindo os bailes funk na favela numa amputação cultural semelhante à ocorrida nos anos 1980, em Brasília, quando a black music contrapunha-se aos homens brancos, filhos de embaixadores, ouvindo The Cure. Por negar um parâmetro de consumo, foi cortada, proibida, porque potência é revolução.

Sensível às práticas perversas colonizadoras, o artista sueco Nikolaj Cyon tentou responder à pergunta "E se a África não tivesse sido colonizada?" desenhando um novo mapa do continente, usando a cartografia como um processo de deslocamento, que está para a geografia, como a escrita está para a palavra falada, é o registro, o que define, prova de um acordo. Cyon constrói mapas sob o título de Alkebu Lan, antiga palavra árabe para definir a África, 
terra do povo negro, para mostrar os territórios dos maiores grupos étnicos antes da Europa chegar, se as fronteiras entre esses grupos tivessem sido mantidas imóveis, em 1600.

Também pensando numa reformulação de fronteiras, o coletivo dinamarquês Superflex na exposição You can't eat identity, vai até a ilha Anjouan, ao norte de Madagascar, no Oceano Índico, para coletar material para uma vídeoinstalação sobre os construtores de barcos. A ilha fica a apenas $70 \mathrm{~km}$ de Mayotte, outra ilha, mas esta, território francês, protegido pelas câmeras de segurança e pela agência Frontex. Mayotte era uma ex-colônia francesa que voltou atrás e pediu para ser francesa de novo, é o pedaço de Europa mais longe do continente, para onde os traficantes de gente, chamados localmente de sonhadores, atravessam por mar aberto pessoas de uma ilha à outra, alguns em busca de um bom hospital ou medicamentos ou apenas para visitar parentes e amigos. Antes da fronteira, eram todos muito próximos e hoje, apesar da dificuldade e do perigo da travessia, ainda mantêm laços. Anjouan é um hyperlink para a situação dos refugiados chegando à Europa, que muitas vezes não se autodenominam refugiados, são pessoas precisando experimentar outras situações de vida. O vídeo do Superflex conta a história do mito de origem da Europa, uma mulher libanesa, que resolveu atravessar o oceano e foi seduzida por Zeus e levada até a llha de Creta, inaugurando o continente. Europa era uma mulher árabe.

No mesmo ímpeto de entender o significado das fronteiras, o escritor e jornalista, colaborador da Chronic (Chimurenga), Sean O'Toole, vai a campo investigar as bordas que separam a África do Sul de Moçambique e do Zimbábue. São 62 quilômetros na divisa com Moçambique e 268, com Zimbábue ${ }^{x V}$. As primeiras configurações fronteiriças eram orgânicas, feitas com plantas sisal que atraíam macacos e elefantes, com a proteção militar ao fundo. Nos anos 1980, o regime do Apartheid construiu a fronteira elétrica reforçando o comprometimento do Estado em prover uma imagem de medo e inovação com tecnologias de segurança: $330 \mathrm{~km}$ de grade elétrica letal. Hoje, a grade não é mais elétrica, mas continua a delinear o aqui e o ali. Não é nada se comparada à cerca elétrica de seis metros de altura de Melilla, território espanhol no norte da África ou aos 8m de altura do muro do West Bank, em Israel. De acordo com o geógrafo francês Michel Foucher, em 2012 havia cerca de 17 muros internacionais cobrindo 7500 quilômetros, ou 3\% das fronteiras existentes. Ele não havia contabilizado o muro anti-imigrantes de $175 \mathrm{~km}$ que está sendo erguido pela Hungria desde 2015 ou aquele que a Bulgária também constrói.

Para mergulhar na busca por territórios espaciais (gaia, a Terra como um único organismo vivo, uma vez que seus componentes físicos estão num complexo interagente) e temporais (antropoceno, referente ao período mais recente da história do Planeta Terra, quando as atividades humanas começaram a ter um impacto global significativo no planeta) utópicos, que desmantelem o capitalismo neoliberal, especulativo e colonizador, o exercício proposto aqui, atentei às pequenas situações sociais que encontrei durante dois meses na África do Sul. O ponto de vista para uma escrita descolonizadora que se deseja aqui, leva em conta uma experiência plural da natureza, não é exclusivamente humano. Atém-se à transmissão de conhecimento oral, costume africano até a chegada colonial, que impôs o livro como objeto sagrado e embora as fontes para os pensamentos aqui reunidos sejam em sua maioria livros, artigos, filmes, vídeoclipes e músicas, grande parte do que consegui captar da África deriva de vivências e conversas. Experimentei aprender a pronúncia para algumas palavras em isiXhosa que colocam a língua de encontro ao céu da boca, fazendo um estalo (clique) que não imaginei que pudesse caber no dia a dia, como quando imitamos o som do cavalgar para uma criança. É perceptível que a vocalização das línguas africanas influencia o português brasileiro, uma das razões pelas quais a etnolinguísta Yeda Pessoa Castro acredita que o brasileiro falado é mais próximo das línguas 
africanas, principalmente da sociedade bantu (Angola, Congo, Moçambique, entre outros povos), oriundas da África-Subsaariana, do que o português brasileiro escrito, mais próximo de Portugal. Nossa forma vocalizada de falar é bantu, nosso jeito de negar duas vezes, como em: não vou, não, também. O momento, no entanto, não é de negar, é de mesclar, sincretizar e olhar adiante, valorizando nossa descendência africana, como fazem os músicos Cadu Tenório e Juçara Marçal e preenchendo lacunas da História com elaborações inventivas.

\section{Considerações finais}

Minha proposta neste artigo foi analisar obras artísticas que abalam estruturas de poder numa situação de mundo fracassado, ainda baseado num modelo de sujeição pela lógica identitária, que vem pelo viés de linguagem-cultura, derivado portanto, de uma matriz branca, logocêntrica, europeia, além de textos de teoria que questionam essas estruturas. Também procurei construir experiências, que fazem com que essas leituras se tornem mais vivas, que dão corpo a essas leituras, o que é inseparável da compreensão do meu próprio processo de inventividade, criação, fabulação artística. O deambular como ferramenta de criar paisagem, como prática estética, como espero que o texto tenha iluminado, são fundamentais para compreensão descolonizada do mundo. Sair da cidade conhecida por todos, à dos guias turísticos, para alcançar suas margens invisíveis, territórios em transformação para enxergar o que está ao redor sem medo do encontro com a alteridade radical, e ir além, como fazia Helio Oiticica com suas "errâncias urbanas". Ele tinha o hábito de pegar um ônibus e se deixar levar até o ponto final para ver onde dava. Os artistas talvez sirvam como "coiotes", os que ajudam os imigrantes ilegais a atravessar fronteiras.

Estes escritos moram numa biblioteca de rua em Nutopia (New + utopia, nome que em português soa ainda mais interessante), micro-nação fundada no dia da mentira em 1973, por Yoko Ono e John Lennon, que satirizavam os problemas de obtenção de visto do inglês Lennon, nos EUA, à época. Nutopia não tem país, fronteiras ou passaporte, somente pessoas e todos seus cidadãos também são seus embaixadores sem leis, que não sejam as cósmicas.



Imagem da exposição Leituras para mover o centro, CCBB RJ, 2016. Fotografia: Mario Grisolli. 


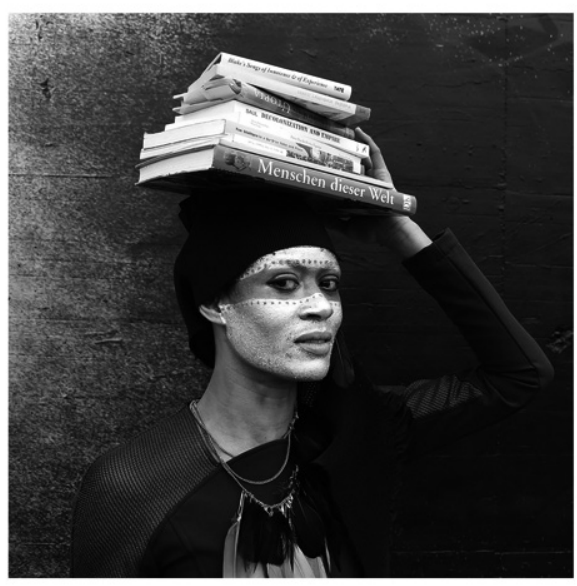

ANNA DE BARROS

NO SEU PLANETA, ANNA CONSTRÓI FARRAPOS DE IDEIAS NO SEU PLANETA, ANNA CONSTROI FARRAPOSDE IDEIAS NOITES ELETRONICAS A ACEITACAO DAS DIFERENCAS DO OUTRO, EM TROCA DEUM PASSINHO NOVO.

NÃO APRENDEU A LÍNGUA MATERNA, QUE NECESSIDADE TERIA? HOJE SE ARREPENDE, PORQUE CAMINHA COM UM VAZIO DE UM LADO E OUTRO, PERTENCENDO A DUAS PARTES A A PARTE ALGUMA.

NOS IDOS DOS ANOS SETENTA DO SÉCULO $X X$, SO HAVIA TRES FAMILIAS AFRICANAS NA SUA METROPOLE. HOJE, PERDEU DE LONGE A CONTA, A PONTO DO CAIXA DO SU PERMERCADO SE DIRIGIR A ELA EM INGLÉS. RESPIRA FUNDO E DESEJA UMA CIDADANIA RLENA MUNDIAL. POR FORA, EXAGERA NA PERFEIÇAO DO ALEMÃO, NOS TREJEITOS BERLINENSES, TAO SEUS, COMO SE DELA PAR TISSE AQUELA CIDADE, A PONTO DE ASSUSTAR COM SUA INTIMIDADE, SEU DOMINIO PLENO SOBRE O TERRITÓRIO, CORTANDO CAMINIHOS POR PONTES INEXISTENTES. $\nabla$
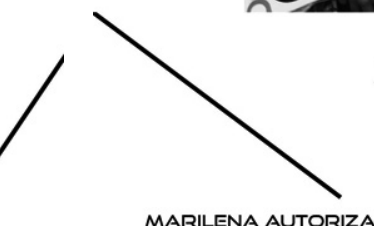

MARILENA VICÊNCIO

MARILENA AUTORIZA-SE APRENDICISMOS CONSTANTEMENTE, REPESSOA-SE ATRAVES DE MODOS, MANEIRA E VIVERES, É MESTRANDA EM VOO LIVRE. TROU XE CONSIGO A CRENCCA COMO BEM E QUANDO CHEGOU AO NOVO PLANETA, DESCOBRIU O QUE MUDARIA SUA VIDA PARA SEMPRE: INTERNET, UNIFORME E PASSE LIVRE PARA ANDAR DE ONIBUS.

LAMBIA RAPADURA SEM CIHUPAR, PARA ESTENDER O TEMPO DE VIAGEM ATE A ESCOLA. MESMO DESPIDA DAS TRANCAS NAGO, OUVIU UMA PORTA BATER ATRAS DE SI. LEVANTOU O QUEIXO E SEGUIU A FAZER RODOPIOS SOBRE TAMPAS DE VENTILADOR, ADAPTANDO A PECA A SEUS PEES CALEJADOS DAS ESTRADAS ANGOLANAS, ONDE CAMINIHAVA FEITO GRILO. NAO SE PODIA RESIGNAR, ERA PRECISO FORCAR OS ENCON TROS, APESAR DO SACI PERERÉ NÄO SER EXATAMENTE O ARONNI.

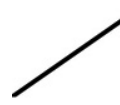

Trabalho realizado com a colaboração de Eliana Moreira Frittrang (Brasil), Marilena Magdalena (Angola), Mariana Sirem Bari (Guiné Bissau). CCBB, 2016.

OLORUM DETERMINOU QUE NOSSA MISSÃO MAIS IMPORTANTE SE DÁ QUANDO ABRACAMOS UMA CAUSA. ELIANA ABRACOU A SAÜDE DA CARNE, QUE ATRAVÉS DO TOQUE E DO CIHEIRO, E TAMBÉM A SAÚDE DA ALMA. AS PESSOAS A PROCURAM PEDINDO AJUDA E TAMBÉM TRANSMITEM MUITO CARINIHO. ISSO A ENCIHE DE ENERGIA.

ELA GOSTA DE NAMORAR E SEGUINDO OS PASSOS DE SEUS ANCESTRAIS, ATRAVESSOU O ATLANTICO PARA ENCONTRAR O AMOR, SEU COMPANIHEIRO HÁ VINTE E CINCO ANOS. PARA ARRENDER A LIINGUA E SE MISTURAR, CUIDAVA DE SENITORAS MAIS VELIHAS E GOSTAVA DE FAZER CURSINIHOS. FAZ LUMINARIAS, ENSINA YOGA E QUER APRENDER BIOCONSTRUCÃO. MESMO DE LONGE, CUIDA DOS QUE FICARAM NA TERRA NATAL.

SOLTOU OS CABELOS QUANDO ATRAVESSOU O MAR, FOI PARTE DO PROCESSO LIBERTADOR, EMITIA TANTA LUZ QUE SO RECEBIA ELOGIOS. NUNCA MAIS PRENDEU. PRATICA O EQUILÍBRIO INTERIOR TODOS OS DIAS E ENSINA AS MÄES BRANCAS DE FILIHOS NEGROS QUE PARA HARMONIZAR, O IMPORTANTE E JUNTAR ENAOO SEPARAR. 
Bedjulinda Fulô conclui, depois de atravessar o Mar do Caribe, o Equador, o Peru, o Acre brasileiro... e chegar finalmente a uma cidade que leva o nome de deus: o Haiti não é este lugar onde o sol escorre a pele às duas da tarde. O menino de quatro anos cobra o português fluente da mãe, que só fala criolo. Fulô quer casar, Fulô quer dar de comer, Fulô quer vencer, Fulô quer voltar. Fulô faz fila onde anunciam vaga de emprego e volta para casa. Não sabe onde vingar a raiva do mundo. É terna e violenta, uma bola de asfalto pesa tonelada sobre sua lombar. Coleciona perdas e derrotas de uma anti-heroína e pergunta insubmissa, depois de mais de hora de conversa em gestos, onde, onde, onde, estaria o ganho por participar de uma coisa assim? Onde?

Texto construído a partir da recusa de duas imigrantes haitianas no Rio de Janeiro em autorizar o uso da imagem para o trabalho. CCBB, 2016.

\section{Bibliografia}

ANDREWS, George Reid. Democracia racial brasileira 1900-1990: um contraponto americano, In: Estudos Avançados. São Paulo: USP, 11 (30), p. 95-105, 1997.

BANDEIRA, Manuel. Estrela da manhã e outros poemas: Antologia Poética. São Paulo: Círculo do Livro, 1978.

BHABHA, Homi K. O Local da Cultura, tradução de Myriam Ávila. Belo Horizonte: Editora UFMG, 1998.

CERTEAU, Michel de. A invenção do cotidiano. Artes de fazer. Petrópolis: Vozes, 1994

CHUDE-SOKEI, Louis. Dr. Satan's Echo Chamber. Chimurenga: África do Sul, 2008.

GUIMARÃES, Bernardo. A Escrava Isaura, Rio de Janeiro: Nova Aguillar, 1976.

MBEMBE, Achille. On the post colony. Berkeley; Los Angeles, California: University of California Press, 2001.

NEGRI, Antonio e HARDT, Michael. Império. Rio de Janeiro, Ed. Record, 2001.

O'TOLLE, Sean. Three men, a fence nd a deadbody. Chronic, Chimurenga, julho 2013. Disponí- vel em http://chimurengachronic.co.za/three-men-a-fence-a-dead-body/. Acesso em: 19 jan. 2016.

RANCIÈRE, Jacques. The Politics of Aesthethics, the distribution of the sensible. Continuum International Publishing Group. Printed in 2004.

ROLNIK, Suely. In: O retorno do corpo-que-sabe, palestra no SESC Vila Mariana, janeiro de 2013, no evento Hemispheric Institute, Instituto hemisférico de performance política. Disponível em:http://hemisphericinstitute.org/hemi/pt/ enc13-keynote-lectures/item/2085-enc13-keynote-rolnik. Acesso em: 10 jul2016.

SAFATLE, Vladimir. O circuito dos afetos: corpos políticos, desamparo e o fim do indivíduo. Belo Horizonte: A utência Editora, 2016.

SANTIAGO, Silviano. Uma literatura dos trópicos. 2a edição. Rio de Janeiro:Ed. Rocco. 2000.

VIRILIO, Paul. Estética da desaparição. Rio de Janeiro: Contraponto, 2015. (Coleção ArteFíssil, direção: Tadeu Capistrano) 
I Ana Hupe. Doutora em Linguagens Visuais pela EBA - Universidade Federal do Rio de Janeiro, Brasil. Contatos: anahupe@gmail.com; anahupe.com

II Traduzido do trecho em inglês: But rather than emphasizing the angstof this space of discontinuity, the beat is a joyful adrenaline rush. The ritual participant enters into the gateways of trance and encounters the possibilities of a freedom unheard of in the world of narrative, the world of hierarchical domination where time and perception are constructions of those classes and races in power. For the descendants of slaves for whom "work" is still tainted by the inequalities of a system based on White European domination and rigid class hierarchies, this "break" is a moment of liberation that is pregnant with deep-seated historicaly eamings and utopian visions.

III Continuando a descrição iniciada no capítulo anterior, trecho traduzido pela autora: "A partilha do sensível revela quem pode ter uma parte do que é comum para a comunidade com base no que fazem e no tempo e no espaço em que esta atividade é realizada. Ter uma "ocupação" em particular, assim, determina a capacidade ou incapacidade para assumir o comando do que é comum para a comunidade; (...) Do inglês: "The distribution of the sensible reveals who can have a share in what is common to the community based on what they do and on the time and space in which this activity is performed. Having a particular 'occupation' thereby determines the ability or inability to take charge of what is common to the community; (...)"

IV Movimento de libertação das colônias africanas e de união dos países africanos.

V A partir de 1940 até o presente, os censos nacionais vêm documentando disparidades persistentes entre as populações branca e não-branca em educação, realização vocacional, ganhos e expectativas de vida. Levantamentos realizados em pesquisas têm demonstrado que as atitudes e estereótipos racistas referentes a negros e mulatos estão amplamente disseminados por toda a sociedade brasileira.

VI Depois do ritual de matar o outro, comido por toda a tribo, o guerreiro escolhido para a tarefa, sai em retiro de até um ano, quando vai ganhando outros desenhos no corpo e até mesmo outro nome, ao longo da assimilação desse devir da subjetividade. Sensações e afetos que vão ser performatizados, vão tornar sensíveis, no corpo, os efeitos dessa transformação pela qual o guerreiro passou. $O$ efeito dessa transformação para a tribo é fundamental. A partir da absorção dos efeitos do outro no corpo, a tribo passa por um processo de reinvenção de si. Os tupinambás aceitavam facilmente abrir mão de vários aspectos da cultura deles, como também os retomavam com facilidade, se fosse necessário, isso levou os jesuítas portugueses a considerarem os indígenas "almas inconstantes", que acabou por gerar o título "A inconstância da alma selvagem" ao livro de Eduardo Viveiros de Castro. O único valor do qual os tupinambás se recusavam a abrir mão era o ritual antropofágico. Os portugueses queriam que eles fizessem isso para incorporarem os inimigos mortos como escravos, eles preferiam dar um membro da tribo como escravo a deixar de realizar o ritual, que era o coração daquela cultura.

VII ROLNIK, Suely. Disponível em: O retorno do corpo-que-sabe, palestra no SESC Vila Mariana, janeiro de 2013, no evento Hemispheric Institute, Instituto hemis- férico de performance política. Disponível em: http://hemisphericinstitute.org/hemi/pt/enc13-keynote-lectures/ item/2085-enc13-keynote-rolnik. Acesso em: 10 jul 2016.

VIII Hoje, o Brasil tem cerca de 200 milhões de habitantes e a África do Sul, 50 milhões.

IX MBEMBE, Achille. The way I see it - The Internet is Afropolitan. In: Chronic, Chimurenga. Março, 2015. Traduzido pela autora do inglês: "I told you about the 1 million Chinese. In Angola and Mozambique, over the last Five years, we have witnessed there turn of 18.000 Portuguese, some of whom had left during the colonisation, others Just coming in. You have people coming in from South Asia, Moroccans coming from the north, and establishing themselves in major cities in South Africa."

$\mathrm{X} O$ embate com a língua afrikaans é ainda mais acirrado, trata-se de um dialeto derivado do holandês, falado pelos brancos sul-africanos.

XI MILLI B, Miss. Disponível em: http://missmillib.co.za/colu$\mathrm{mn}$-that-time-my-privilege-got-the-better-of-my-sensibilities/. Acesso em: 10 jan. 2016. Traduzido pela autora a partir deste original: "This black South African manhas no ambitions to excel in the English language. He thought it interesting that I should correct him about a language that is not his own, in a language that is not my own. He said he wished I had done it to him attempting to speak my home language of is isXhosa, which he does not speak. "Decolonizing is practice, you know", He declared. "We may communicate in the oppressor's language but, I don't respect it enough to want to be good at it". I kept guard of my words when I realized that I had Just reenacted a scene I saw too many times and hated as a child but He externalized them. "You Just reminded me of my white school teachers who used to beat this language in to us", he said with a smile that disarmed my defensive position so that this exchange unfolded like a conversation between a teacher and a student. I didn't feel bad more than I felt misunderstood. In my mind, I wasn't one of those judgmental Anglophile black people because l'm "conscious", I'm "woke", I understand how oppressive systems work."

XII A Flupp, em 2015, organizou o Rio Slam Poetry, com 16 poetas do mundo todo.

XIII MBEMBE, Achille. On the Postcolony. University of California Press. Berkeley and Los Angeles, California. 2001. Traduzido pela autora do original: "Africa is never seen as possessing things and attributes properly part of "human nature." Or, when it is, its things and attributes are generally oflesser value, little importance, and poor quality. It is this elementariness and primitiveness that makes Africa the world par excellence of all that is incomplete, mutilated, and unfinished, its historyr educed to a series of set backs of nature in its quest for humankind."

XIV Em palestra no Centro de Artes da Maré, em 19 de maio de 2016, dentro do evento Micro utopias, organizado pelo Creative Lab.

XV O'TOLLE, Sean. Three men, a fence and a dead body. In: Chronic, Chimurenga, julho 2013. Disponível em: http://chimurengachronic.co.za/three-men-a-fence-a-dead-body/. Acesso em: 19 Jan. 2016. 